\title{
Diversité des techniques de séparation du sagou de son support, dans la province du Sépik-est (Papouasie Nouvelle-Guinée)
}

\section{Christian Coiffier}

\author{
(2) OpenEdition \\ Journals \\ Édition électronique \\ URL : https://journals.openedition.org/tc/585 \\ DOI : $10.4000 /$ tc. 585 \\ ISSN : 1952-420X \\ Éditeur \\ Éditions de l'EHESS
}

\section{Édition imprimée}

Date de publication : 1 mars 1995

ISSN : 0248-6016

\section{Référence électronique}

Christian Coiffier, «Diversité des techniques de séparation du sagou de son support, dans la province du Sépik-est (Papouasie Nouvelle-Guinée) », Techniques \& Culture [En ligne], 22 | 1995, mis en ligne le 30 décembre 2005, consulté le 29 septembre 2022. URL : http://journals.openedition.org/tc/585 DOI : https://doi.org/10.4000/tc.585

Ce document a été généré automatiquement le 29 septembre 2022

Tous droits réservés 
Diversité des techniques de séparation du sagou de son support, dans la province du Sépik-est (Papouasie Nouvelle-Guinée)

Christian Coiffier 